\begin{tabular}{|c|c|c|c|c|c|c|c|c|c|}
\hline \multirow[b]{2}{*}{$\begin{array}{l}\text { Method } \\
\text { number }\end{array}$} & TABLE I-COMPARIS & N OF $\mathrm{Mi}$ & gested 5 & rs. after & & & seces & & \\
\hline & METHOD USED & $\begin{array}{l}\text { No. of } \\
\text { detns. }\end{array}$ & $\underset{\operatorname{Max}}{\mathrm{Pe}}$ & $\begin{array}{l}\text { ent nit } \\
\text { Min. }\end{array}$ & Av. & $\begin{array}{l}\text { No. of } \\
\text { detns. }\end{array}$ & $\begin{array}{l}P \\
\text { Max. }\end{array}$ & $\begin{array}{l}\text { ent ni } \\
\text { Min }\end{array}$ & \\
\hline 1 & $\begin{array}{l}\mathrm{K} \text { jeldahl (nlodified) }_{\text {Official: }} \\
50 \mathrm{cc} . \mathrm{H}_{2} \mathrm{SO}_{4}+0.7 \mathrm{~g} \cdot \mathrm{Hg}+\mathrm{KMnO}_{4} \ldots \ldots\end{array}$ & 4 & 8.38 & 8.34 & 8.36 & 5 & 8.30 & 8.22 & \\
\hline 2 & $\begin{array}{l}\text { Kjeldahl (modified) Official: } \\
30 \text { cc. } \mathrm{H}_{2} \mathrm{SO}_{4}+0.7 \mathrm{~g} . \mathrm{Hg}+20 \mathrm{cc} . \mathrm{H}_{2} \mathrm{SO}_{4} \text { (added later) }+\mathrm{KMnO}_{4} . .\end{array}$ & 5 & 8.45 & 8.38 & 8.41 & 2 & 8.34 & 8.32 & \\
\hline 31 & $\begin{array}{l}\text { Kjeldahl-Gunning-Arnold, modified by ussing } \mathrm{KMnO}_{4} \text { and excess } \mathrm{H}_{2} \mathrm{SO}_{4} \text { : } \\
50 \mathrm{cc} \cdot \mathrm{H}_{2} \mathrm{SO}_{4}+0.7 \mathrm{~g} \cdot \mathrm{Hg}+10 \mathrm{~g} \text {. } \mathrm{K}_{2} \mathrm{SO}_{4}+\mathrm{KMnO}_{4} \ldots \ldots \ldots \ldots \ldots\end{array}$ & 5 & 8.10 & 7.95 & 8.04 & 2 & 8.15 & 8.14 & \\
\hline 4 & 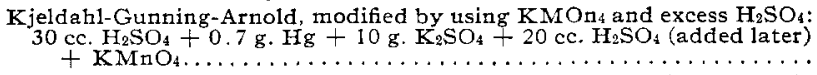 & 5 & 8.29 & 8.20 & 8.26 & .. & $\ldots$ & . & \\
\hline 51 & $\begin{array}{l}\text { Kjeldahl-Gunning-Arnold, modified by using excess } \mathrm{H}_{2} \mathrm{SO}_{4} \text { (no } \mathrm{KMnO}_{4} \text { ): } \\
30 \mathrm{cc} \cdot \mathrm{H}_{2} \mathrm{SO}_{4}+0.7 \mathrm{~g} . \mathrm{Hg}+10 \mathrm{~g} . \mathrm{K}_{2} \mathrm{SO}_{4}+20 \mathrm{cc} . \mathrm{H}_{2} \mathrm{SO}_{4} \text { (added later). }\end{array}$ & 5 & 8.28 & 8.19 & 8.22 & .. & $\cdots$ & $\cdots$ & \\
\hline 61 & 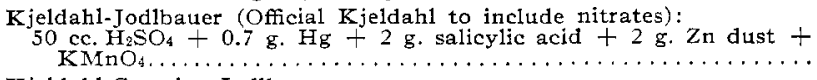 & 8 & 8.29 & 8.18 & 8.23 & . & $\cdots$ & $\cdots$ & \\
\hline 71 & 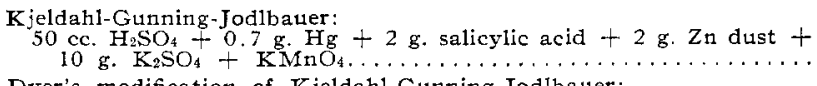 & 5 & 8.28 & 8.16 & 8.24 & . & $\cdots$ & $\cdots$ & \\
\hline 81 & 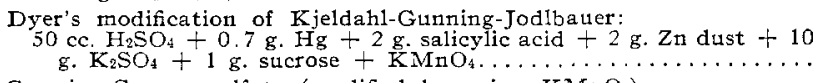 & 6 & 8.33 & 8.21 & 8.27 & 3 & 8.28 & 8.27 & \\
\hline 96 & $\begin{array}{l}\left.\text { Gunning-Copper sulfate (modified by using } \mathrm{KMnO}_{4}\right): \\
50 \text { cc. } \mathrm{H}_{2} \mathrm{SO}_{4}+0.2 \mathrm{~g} . \mathrm{CuSO}_{4}+10 \mathrm{~g} \cdot \mathrm{K}_{2} \mathrm{SO}_{4}+\mathrm{KMnO}_{4} \ldots \ldots \ldots\end{array}$ & 5 & 8.41 & 8.04 & 8.23 & 5 & 8.30 & 8.20 & \\
\hline 10 & $\begin{array}{l}\text { Gunning-Copper sulfate: } \\
50 \mathrm{cc} . \mathrm{H}_{2} \mathrm{SO}_{4}+0.2 \mathrm{~g} . \mathrm{CuSO}_{4}+10 \mathrm{~g} . \mathrm{K}_{2} \mathrm{SO}_{4} \ldots \ldots .\end{array}$ & 5 & 8.26 & 8.25 & 8.25 & .. & $\ldots$ & $\cdots$ & \\
\hline 11 & $\begin{array}{l}\text { Official Gunning: } \\
50 \text { cc. } \mathrm{H}_{2} \mathrm{SO}_{4}+10 \mathrm{~g} . \mathrm{K}_{2} \mathrm{SO}_{4} .\end{array}$ & 6 & 8.27 & 8.09 & 8.17 & . & $\ldots$ & $\cdots$ & \\
\hline 12 & $\begin{array}{l}\text { Vanadium-Gunning: } \\
50 \mathrm{cc} . \mathrm{H}_{2} \mathrm{SO}_{4}+10 \mathrm{~g} . \mathrm{K}_{2} \mathrm{SO}_{4}+0.2 \mathrm{~g} . \mathrm{V}_{2} \mathrm{O}_{5}(a) \ldots\end{array}$ & . & & $\ldots$ & $\cdots$ & 6 & 8.12 & 7.96 & \\
\hline
\end{tabular}

(a) Experiment Station Record, 32, 310.

\begin{tabular}{|c|c|c|c|c|c|c|c|c|c|c|c|c|c|c|c|c|c|c|c|c|c|}
\hline \multirow{2}{*}{\multicolumn{2}{|c|}{$\begin{array}{l}\text { DETERMINATION } \\
\text { METHOD: }\end{array}$}} & \multicolumn{6}{|c|}{$\begin{array}{r}\text { Tabie II-Pero } \\
\text { Nitrogen IN Casein } \\
\text { Kjeldahl-Gunning-Arnold }\end{array}$} & \multicolumn{7}{|c|}{$\begin{array}{l}\text { GEN IN CASEIN AND PIGS BY } \\
\text { NITROGEN IN LOT II PIGS } \\
\text { Kjeldahl-Gunning-Arnold }\end{array}$} & \multicolumn{7}{|c|}{$\begin{array}{l}\text { Nitrogen IN Lor II PIGs } \\
\text { Gunning-Copper Sulfate }\end{array}$} \\
\hline & & \multicolumn{3}{|c|}{$\begin{array}{l}\text { TOTAL HEATING } \\
\text { Mitutes }\end{array}$} & \multicolumn{3}{|c|}{$\begin{array}{l}\text { Hours heating } \\
\text { after clearing }(a)\end{array}$} & \multicolumn{4}{|c|}{$\begin{array}{c}\text { Total HeATING } \\
\text { Minutes }\end{array}$} & \multirow{2}{*}{\multicolumn{3}{|c|}{$\begin{array}{l}\text { Hours heating } \\
\text { after clearing }(b)\end{array}$}} & \multicolumn{4}{|c|}{$\begin{array}{l}\text { Toral Heating } \\
\text { Minutes }\end{array}$} & \multicolumn{3}{|c|}{$\begin{array}{l}\text { Hours heating } \\
\text { after clearing }(b)\end{array}$} \\
\hline UMBER & 15 & 30 & 5 & 60 & 1 & ted & $8 \times 5$ & 15 & 30 & & 60 & & & 8 & 15 & 30 & 45 & 60 & 1 & 3 & 5 \\
\hline $1 \mathrm{~A}$ & $\begin{array}{l}13 \cdot 23 \\
13.36\end{array}$ & $\begin{array}{l}13.89 \\
13.87\end{array}$ & 14.20 & 14.46 & 14.56 & $\begin{array}{l}14.64 \\
14.62\end{array}$ & $\begin{array}{l}14.39 \\
14.49\end{array}$ & .32 & $\begin{array}{l}8.06 \\
8.05\end{array}$ & $\begin{array}{l}8.06 \\
7.97\end{array}$ & $\begin{array}{l}7.91 \\
7.88\end{array}$ & $\begin{array}{l}8.18 \\
8.17\end{array}$ & $\begin{array}{l}8.3 \\
8.3\end{array}$ & Los & .33 & 7.63 & & 4 & 13 & & \\
\hline $2 \quad \mathrm{C}$ & $\begin{array}{l}13.39 \\
13.49\end{array}$ & $\begin{array}{l}13.96 \\
\text { Lost }\end{array}$ & 4 & 14.44 & .53 & $\begin{array}{l}14.57 \\
14.67\end{array}$ & $\begin{array}{l}14 \cdot 41 \\
14.54\end{array}$ & 7.59 & $\begin{array}{l}7.71 \\
7.73\end{array}$ & $\begin{array}{l}8.16 \\
8.15\end{array}$ & $\begin{array}{l}8.13 \\
8.12\end{array}$ & $\begin{array}{l}8.20 \\
8.23\end{array}$ & 8. & & $1.05=$ & 4 & 7. & & 1 & 8. & \\
\hline$V \mathbf{E}$ & 13.37 & 13.91 & .22 & 14.45 & 4.55 & 14.62 & 4.46 & .44 & 7.89 & 8.09 & 8.01 & 8.20 & 8.35 & 8.45 & 7.34 & 7.64 & 7.75 & 7.93 & 8.12 & 8.26 & 8.39 \\
\hline $\begin{array}{l}\text { Dry } \\
\text { Dasis } \\
\text { aver. }\end{array}$ & 41 & .00 & 5.33 & 15.58 & 5.68 & 5.77 & .60 & & & & $\cdots$ & $\ldots$ & & & & & & & & & \\
\hline
\end{tabular}

(a) 35 minutes were required until clear.

(b) 70 minutes were required until clear. bumping, the usual frothing resulting from the use of zinc is obviated, and at the same time the distillation of mercury is eliminated. We experienced no further contamination of the condensers or receivers after making this change.

Chemical, Section

IOWA AGRYCULTURAL, EXPERIMENT STATION AMES, IOWA

\section{METHODS FOR THE DETERMINATION OF CARBON DIOXIDE AND A NEW FORM OF ABSORPTION TOWER ADAPTED TO THE TITRI- METRIC METHOD ${ }^{1}$}

By E. Truog

Received April 22, 1915

A large number of different methods and forms of apparatus have been recommended for the determination of carbon dioxide. This is largely due to the fact that the determination is made for a large variety of purposes and under numerous different conditions. In the chemical analyses of soils and in the investigation of soil phenomena, the writer has had numerous occasions to determine carbon dioxide. In such work carbon dioxide is usually determined by one of the three following methods: gas-volumetric, gravimetric, and titrimetric. In order to secure sufficiently accurate results for most purposes with the gas-volumetric method, rather elaborate apparatus is usually required, and hence the method is not used as generally as the others. Station.

\section{THE GRAVIMETRIC METHOD}

The gravimetric method, in which the carbon dioxide is absorbed in a $\mathrm{KOH}$ bulb or other absorbing tubes, gives very accurate results when the large number of precautions are strictly observed. These precautions and the disadvantages of the gravimetric method have been very completely set forth by J. R. Cain. ${ }^{1}$ A precaution often ignored, but of great importance, is in the use of drying reagents of the same hygroscopicity at both ends of the $\mathrm{CO}_{2}$ absorption bulb. The air must be dried to exactly the same degree, both when it enters and leaves the absorption bulb, or there will be an error due to loss or gain of water. In the writer's experience errors from this source may amount to as much as two milligrams. In the case of rapid aspirations of large volumes of gas so much absorbing and drying apparatus is needed that errors in weighing become serious.

\section{THE ALKALI TITRIMETRIC METHOD}

Owing to disadvantages of the gravimetric method, various titrimetric methods have come into use. Of these methods the absorption of the carbon dioxide in a sodium or potassium hydroxide solution and determination of the carbonates by double titration with phenolphthalein and methyl orange has been the most widely used. This method for the absorption and determination of free carbon dioxide was first used by Brown and Escombe. ${ }^{2}$ These investigators apparently 1 Technological Paper, 33, Bur. Standards; also This Journal, 6 (1914), 465 .

2 Phil. Trans., (B) 193 (1900). 289. 
used the method very carefully, as several important precautions were given as follows: Pure sodium hydroxide free from iron and aluminum should be used. The volume should be kept low and in titration, loss of carbon dioxide locally should be prevented by thorough shaking. Contamination by carbon dioxide from the air should also be prevented by proper protection. They recognized the need of standard end points as a control and used vessels of the same shape, containing the same amounts of solution and indicators for the two end points, as were used in the regular analyses. In their check experiments in which varying known amounts of carbon dioxide were determined, the differences between the actual amounts present and those found range from $0.05 \mathrm{cc}$. to nearly $0.20 \mathrm{cc}$. of $0.1 \mathrm{I}$ solution. This causes an error of 0.2 to $0.8 \mathrm{mg}$. of $\mathrm{CO}_{2}$. These investigators, however, make no mention of the amount of indicator used or of the effect of carbon dioxide on the methyl orange end point. Later investigators have shown that these are considerations that need to be taken into account.

Küster ${ }^{1}$ made an extended study of this double titration for carbon dioxide. $\mathrm{He}$ found that pure sodium bicarbonate reacts alkaline to phenolphthalein, even when present in small amounts. A rise of temperature makes the reaction more marked. An addition of sodium chloride depresses the reaction. $\mathrm{He}$ concludes that phenolphthalein is not suitable as an indicator for the accurate determination of alkali carbonates.

Nol12 after an extended investigation comes to the conclusion that the correct results can be obtained only by use of phenolphthalein in the proper amount. The amount of phenolphthalein to be used is to be regulated by the amount of carbonates present. He also states that it is permissible to have only a small amount of carbonates present.

Auerbach ${ }^{3}$ in studying the determination of carbonates in water states that the titration should only be made in case of small amounts of carbonates and with very dilute amounts of phenolphthalein, otherwise it is necessary to make a correction. He used j drops of a phenolphthalein solution which contained one gram in $500 \mathrm{cc}$. He used a dilution of about $300 \mathrm{cc}$, and states that higher concentrations of indicator require larger amounts of carbon dioxide to dispel the color, while higher concentrations of bicarbonate prevent to a certain extent the formation of the color.

The writer has investigated this double titration method to a certain extent. A solution of sodium carbonate was prepared as follows: Kahlbaum's sodium bicarbonate which gave no test for chlorides or sulfates was used. A I $7 \mathrm{~g}$. sample of this was placed in a platinum dish and heated at $300^{\circ} \mathrm{C}$. to constant weight in an electric furnace. The sodium carbonate was dissolved in $2000 \mathrm{cc}$. of $\mathrm{CO}_{2}$ free water giving an approximately o.r $N$ solution. Measured portions of this solution were titrated against sulfuric acid solution

1 Z. anorg. Chem., 13 (1897), 127.

2 Z. angew. Chem, 25 (1912), 998

3 Ibid., 25 (1912), 1722 of slightly less than o.I $N$ strength. All measuring instruments used in this work had been carefully calibrated. The phenolphthalein solution used contained one gram in $100 \mathrm{cc}$. of alcohol. The methyl orange solution contained one gram in I000 cc. of water. In the titrations of Table I two drops of phenolphthalein and one drop of methyl orange were used. The titrations were made in Erlenmeyer flasks, and the solutions were always diluted with such amounts of $\mathrm{CO}_{2}$-free water as to make the final volume after titration close to $200 \mathrm{cc}$.

Standard end points for each titration were also used. The one for the phenolphthalein end point consisted of an Erlenmeyer flask similar to the one used in the regular titration, and to which was added $200 \mathrm{cc}$. of water and two drops of phenolphthalein. Since carbon dioxide has a very appreciable effect on methyl orange, it is necessary to vary this end point according to the amount of carbonates that are titrated. Carbon dioxide in amounts equal to those liberated in the titrations were added to $200 \mathrm{cc}$. of water containing one drop of methyl orange. The end points for each case were then made by adding o. I $N$ sulfuric acid to $200 \mathrm{cc}$. of water until the color of the methyl orange indicated just a little stronger acidity than the corresponding one with carbonic acid. The end points with carbonic acid are not permanent because of escape of carbon dioxide, and hence it is necessary to make them with a non-volatile acid in which case they remain constant for several days.

In making the titration with phenolphthalein, the tip of the burette, which had been lengthened, was allowed to dip below the surface of the solution in the flask until near the end point, when it was raised. This procedure eliminates, largely, the possibility of escape of carbon dioxide due to local concentration of the mineral acid at the surface. This may also be accomplished by thoroughly shaking the flask and adding the acid very slowly. Such a procedure, however, may introduce other errors, since the vigorous shaking increases the opportunity for absorption of carbon dioxide during the first part of the titration; and may introduce an error in the opposite direction during the last part of the titration. An error due to the latter cause is apparently possible on considering the following: To $25 \mathrm{cc}$. of approximately o. I $N \mathrm{Na}_{2} \mathrm{CO}_{3}$ solution, diluted with water to I $75 \mathrm{cc}$, were added two drops of phenolphthalein and then o.I $\mathrm{N} \mathrm{H}_{2} \mathrm{SO}_{4}$ till the pink color was dispelled. The flask containing this solution was now placed in a Camp shaker and shaken for five minutes, when the solution was again distinctly colored. It took $0.3 \mathrm{cc}$. more of 0. I $N$ acid to change this color to the same shade as the blank which was not shaken. This is evidently due to loss of carbon dioxide. By simply letting the solution stand the same phenomenon will take place after several hours. After several days the solutions will become strongly colored. Table I gives a few of the results which have been obtained by following the procedure outlined.

If the method is to give correct results, then the titration with phenolphthalein should be just one-half 
of the total on continuing to the methyl orange end point. From Table $I$ it is evident that the method has given very good results when not aver 25 cc. of o. I $N$ $\mathrm{Na}_{2} \mathrm{CO}_{3}$, equivalent to approximately $50 \mathrm{mg}$. of $\mathrm{CO}_{2}$, was present. If larger amounts of carbonates are present, then the end point with phenolphthalein comes

\begin{tabular}{|c|c|c|c|c|}
\hline \multicolumn{5}{|c|}{ ns approximately $0.1 \mathrm{~N}$ and all figures represent $\mathrm{cc}$. } \\
\hline$\underset{\substack{\mathrm{Na}_{2} \mathrm{CO}_{3} \\
\text { taken }}}{ }$ & $\begin{array}{l}\text { Phenol } \\
\text { Calculated }\end{array}$ & $\begin{array}{l}\text { athalein } \\
\text { Consumed }\end{array}$ & $\begin{array}{l}\text { Methy } \\
\text { Calculated }\end{array}$ & $\begin{array}{l}\text { orange } \\
\text { Consumed }\end{array}$ \\
\hline 10 & 5.53 & 5.48 & 11.06 & 11.05 \\
\hline 10 & 5.53 & 5.50 & 11.06 & 11.10 \\
\hline 25 & 13.81 & 13.76 & 27.62 & 27.68 \\
\hline 25 & 13.81 & 13.75 & 27.62 & 27.55 \\
\hline 50 & 27.62 & 27.20 & 55,24 & 55.15 \\
\hline 50 & 27.62 & 27.15 & 55,24 & 55.00 \\
\hline 75 & 41.43 & 40.91 & 82.86 & 82.76 \\
\hline
\end{tabular}

too soon when only two drops of indicator are present. In two other trials not given above it was found as follows:

When $50 \mathrm{cc}$. of $\mathrm{Na}_{2} \mathrm{CO}_{3}$ were taken, it required four drops of phenolphthalein to bring the end point at the proper place. Similarly with $0.5 \mathrm{cc}$. of phenolphthalein and $50 \mathrm{cc}$. of $\mathrm{Na}_{2} \mathrm{CO}_{3}$ an excess of I. IO cc. of acid was used.

Thus, if too little phenolphthalein is used in proportion to the amount of $\mathrm{CO}_{2}$ present, then the end point comes too soon; and if the reverse condition obtains, then the true end point is overstepped. That such is the case can also be shown in the following simple manner: To $50 \mathrm{cc}$. of $0 . \mathrm{I} \mathrm{N} \mathrm{Na}_{2} \mathrm{CO}_{3}$ diluted to about $100 \mathrm{cc}$, are added two drops of phenolphthalein and then acid till the color disappears. If more phenolphthalein is now added, the color will again appear, and the intensity will depend upon the amount of phenolphthalein added as well as the temperature and the amount of shaking and length of time the solution stands.

The results just given are in full accord with those of the investigators already cited. In order to obtain correct results it is absolutely necessary to regulate the amount of phenolphthalein used according to the amount of carbonates present. If precautions are not taken in regard to the use of phenolphthalein and to the effect of $\mathrm{CO}_{2}$ on the methyl orange end point, then two errors enter into the determination; but since they are in opposite directions when only small amounts of phenolphthalein are used, they compensate to a certain degree. It is possible that because of this compensation, Brown and Escombe ${ }^{1}$ were able to get as good results as they did, apparently without regard to these precautions. The evidence is conclusive that in order to be assured of correct results with the couble titration method for carbonates, several precautions need to be carefully observed. To observe all these precautions causes considerable inconvenience.

It should also be noted that the end points, especially with phenolphthalein, are not at all sharp or positive, and thus it is possible to make the titration only under the best conditions of light. Even under such conditions many persons find it absolutely impossible to discern the true end points because of the gradual color change. The method thus leaves much to be desired.

${ }^{1}$ Loc. cit.
Bowser $^{1}$ recommends the use of $\mathrm{KOH}$ instead of $\mathrm{NaOH}$ for the absorption of the $\mathrm{CO}_{2}$ and states that it is more satisfactory. The writer has found that this gives a slightly better end point with phenolphthalein than when $\mathrm{NaOH}$ is used, but the improvement is not sufficient to make the method satisfactory. Bowser also recommends the addition of ro to $15 \mathrm{cc}$. of ethyl alcohol to further improve the end point. When solutions of $\mathrm{Na}_{2} \mathrm{CO}_{3}$ and $\mathrm{K}_{2} \mathrm{CO}_{3}$ to which phenolphthalein has been added are brought to the colorless point with acid and then allowed to stand, the resultant solution of $\mathrm{NaHCO}_{3}$ regains its color much more rapidly than the solution of $\mathrm{KHCO}_{3}$. This is undoubtedly due to the greater dissociation or breaking up of the $\mathrm{NaHCO}_{3}$ and loss of $\mathrm{CO}_{2}$ by dissipation to the air. The action of the alcohol probably consists in retarding this dissociation and preventing the loss of $\mathrm{CO}_{2}$ to the air because of its greater solubility in alcohol than in water. The writer has found no advantage in the use of the alcohol and, as is well known, it decreases greatly the sharpness of the methyl orange end point.

THE BARIUM HYDROXIDE TITRIMETRIC METHOD

In search of a better method the writer was led to try the method of absorption in a measured excess of $\mathrm{Ba}(\mathrm{OH})_{2}$ in which the carbon dioxide is precipitated as $\mathrm{BaCO}_{3}$ which is practically neutral to phenolphthalein. The excess of $\mathrm{Ba}(\mathrm{OH})_{2}$ is then easily determined by titration, and thus by difference the amount of $\mathrm{CO}_{2}$ is quickly determined. The principle of the method is essentially that of the C. Winkler titration method for carbon dioxide and carbonates. This method has the advantage of a good end point. The presence of the precipitate of $\mathrm{BaCO}_{3}$ in the solution in which the titration is made may appear objectionable, but the experimental data show that the presence of the precipitate has absolutely no harmful effects. The precipitate, being pure white, aids rather than hinders the eye in detecting the end point. Küster ${ }^{2}$ gives considerable data which show conclusively that carbonates can be determined with great accuracy by this method.

The writer has tested the method as follows: Measured quantities of standard $\mathrm{Ba}(\mathrm{OH})_{2}$ were treated with excess of $\mathrm{CO}_{2}$, and then boiled to expel the excess and change all bicarbonate to normal carbonate. Measured quantities of $\mathrm{Ba}(\mathrm{OH})_{2}$ and four drops of phenolphthalein were added to these samples. Standard acid was then added till the color disappeared. The results showed that $\mathrm{Ba}(\mathrm{OH})_{2}$ could be determined in the presence of $\mathrm{BaCO}_{3}$ very accurately. The experimental results never varied from the calculated by more than one drop of O.I 5 acid and the end point was always good.

J. R. Cain ${ }^{3}$ recommends the absorption of the $\mathrm{CO}_{2}$ in $\mathrm{Ba}(\mathrm{OH})_{2}$ and after filtering off and washing the $\mathrm{BaCO}_{3}$, titrates it with standard acid. For very small amounts of $\mathrm{CO}_{2}$ this is undoubtedly a very good method, and Cain has outlined a procedure for filtering and washing that has given excellent results. When larger

\footnotetext{
This Journal, 4, pp. 203, also 265.

$2 Z$. angew. Chem., 13 (1897), 127.

Loc. cit.
} 
amounts of $\mathrm{CO}_{2}$ are to be determined, then the washing of the precipitate becomes more troublesome, and there is nothing to be gained by this procedure over that of titrating the excess of $\mathrm{Ba}(\mathrm{OH})_{2}$.

A serious objection to the method of titrating the excess of $\mathrm{Ba}(\mathrm{OH})_{2}$ has been that of securing complete absorption in the case of rapid aspirations carrying considerable amounts of $\mathrm{CO}_{2}$. The ordinary form of absorption towers with glass beads, as are used with alkali hydroxides, are not adapted for use with $\mathrm{Ba}(\mathrm{OH})_{2}$ since in this case a precipitate is formed which prevents complete washing. When the aspiration is slow, and small amounts of $\mathrm{CO}_{2}$ are to be absorbed, Meyer bulb tubes are a satisfactory form of absorption apparatus. Brady ${ }^{1}$ has described an arrangement adapted for such purposes.

\section{A NEW FORM OF ABSORPTION TOWER}

In an attempt to secure an absorption apparatus for use with $\mathrm{Ba}(\mathrm{OH})_{2}$ that would be satisfactory for both slow and rapid aspirations, carrying either small or large amounts of $\mathrm{CO}_{2}$, the writer has devised the absorption tower shown in Fig. I. This apparatus consists of a $500 \mathrm{cc}$. suction flask (A), a glass tube

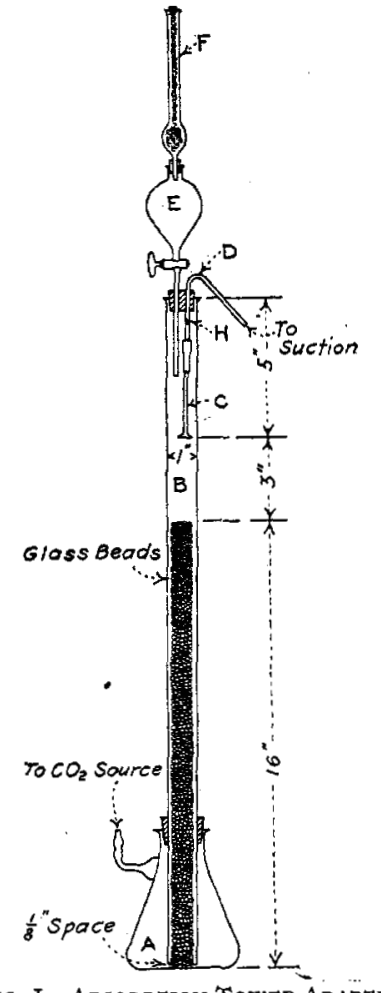

Fig. I-ABsorption Tower ADAPTED TO THE USE OF BARIUM HYDROXIDF FOR THE ABSORPTION AND TITRIMETRIC DETERMINATION OF CARBON DrOXIDE

water are quickly poured into the funnel and the soda-lime tube is replaced. This water is now allowed to run into the tower, thus washing the funnel free of $\mathrm{Ba}(\mathrm{OH})_{2}$, The suction draws the absorbing solution up into the tower. The apparatus is now ready for the absorption of $\mathrm{CO}_{2}$. When the absorption is complete, the suction is closed off with a pinch-cock or stop-cock and the stop-cock of $(\mathrm{E})$ is gradually opened

1 ThIS JoURnaL, 6 (1914), 843. allowing $\mathrm{CO}_{2}$-free air to enter, when the absorbing solution settles into the flask. The flask is next disconnected from the source of $\mathrm{CO}_{2}$ and after the solution has settled into the flask, the stop-cock of (E) is closed. The air in $(E)$ is now free from $\mathrm{CO}_{2}$ and ready for the next determination. The stopper at the top of the tower is raised and the extending tubes washed off into the tower with a little $\mathrm{CO}_{2}$-free water. The tower is raised a few inches from the flask, when the beads slide out. If they stick to the tower, a little gentle tapping at the top suffices to make them drop. The inside of the tower is immediately rinsed with about $100 \mathrm{cc}$. of $\mathrm{CO}_{2}$-free water poured from a beaker. The tower is raised and removed after also washing off the lower end on the outside. Four drops of phenolphthalein are added and the excess of $\mathrm{Ba}(\mathrm{OH})_{2}$ is immediately titrated.

By following the directions as given, the flask and tower are filled with $\mathrm{CO}_{2}$-free air previous to washing. The washing is quickly and easily made, and if the flask is then corked or the titration immediately made, there is scarcely any chance for contamination from the air. The $\mathrm{Ba}(\mathrm{OH})_{2}$ is delivered directly from a burette into the funnel (E) which contains $\mathrm{CO}_{2}$-free air. The soda-lime tube (F) is always replaced as quickly as possible. In the titration the flask is shaken continuously to prevent local action of the acid on the $\mathrm{BaCO}_{3}$ and possible loss of $\mathrm{CO}_{2}$. The glass beads cause no hindrance in the titration. A little $\mathrm{BaCO}_{3}$ may stick to the sides of the tower, but this need not be completely washed out as it does not enter into the titration. After titration a little strong acid is added to the flask to dissolve the $\mathrm{BaCO}_{3}$. The beads are then poured onto a scoop-shaped screen, washed under the tap, rinsed with distilled water and poured back into the tower, which has been replaced in the flask.

Perforated glass beads should be used in preference to the solid spherical kind, as they break up the bubbles more completely and increase the efficiency of the absorption. In the old form of towers, perforated beads could not be used advantageously, since they made complete washing very difficult. This objection is entirely done away in this form of tower. If solid spherical beads are used they should be mixed with some short pieces of glass tubing in order to leave sufficient pore space for the absorbing solution. Alkali hydroxides may be used also with this form of tower and the absorbed $\mathrm{CO}_{2}$ may then be determined by double titration, or better, by adding an excess of $\mathrm{BaCl}_{2}$ and then titrating the $\mathrm{BaCO}_{3}$ after neutralizing the excess of hydroxide. The best plan of all is to use a standard solution of $\mathrm{Ba}(\mathrm{OH})_{2}$ to absorb the $\mathrm{CO}_{2}$. Solutions of $\mathrm{Ba}(\mathrm{OH})_{2}$ free from carbonates are much more easily prepared than those of the alkalies. By using a sufficiently large tower there is no trouble in getting complete absorption with $\mathrm{Ba}(\mathrm{OH})_{2}$ even with rapid aspirations. A tower of the height in the figure suffices for most purposes. If the aspiration is extremely rapid the column of beads should be increased to twenty inches in height. The precipitate of $\mathrm{BaCO}_{3}$ aids in the absorption, by checking the movement of gas bubbles. 


\section{REAGENTS}

STANDARD HYDROCHLORIC ACID SOLUTION-A $0.4 \mathrm{~N}$ solution is employed.

BARICM HYDROXIDE SOLUTION-A $0.4 N$ solution is prepared as follows: Dissolve $80 \mathrm{~g}$. of $\mathrm{Ba}(\mathrm{OH})_{2} .8 \mathrm{H}_{2} \mathrm{O}$ in $1000 \mathrm{cc}$. of water, heat to boiling and then filter with a Buchner funnel into a stock bottle which has been freed of $\mathrm{CO}_{2}$. A double filter paper is carefully laid on the funnel and drawn down and then the funnel is never allowed to suck dry till the solution has all gone through. In this way a solution free of carbonates is much more quickly and easily prepared than by allowing the precipitate to settle and siphoning over. The burette and appropriate guards are then attached and the proper dilution is made after titrating against the standard acid.

PHENOLPHTHALEIN SOLUTION-One gram of the indicator is dissolved in Ioo cc. of ethyl alcohol.

\section{ACCURACY OF METHOD}

In order to test the efficiency of the apparatus and technique in preventing the contamination of the $\mathrm{Ba}(\mathrm{OH})_{2}$ by the $\mathrm{CO}_{2}$ of the air, measured quantities of the $\mathrm{Ba}(\mathrm{OH})_{2}$ were placed in the tower in the regular way, and after aspirating $\mathrm{CO}_{2}$-free air through the apparatus for some time, the solution was removed in the regular way and titrated. The titrations disclosed no measurable quantities of $\mathrm{CO}_{2}$, and hence the contamination is practically entirely prevented. In order to test the efficiency of the absorption with this tower, measured quantities of the $\mathrm{Ba}(\mathrm{OH})_{2}$ solution were treated with $\mathrm{CO}_{2}$ and after boiling to expel the excess of $\mathrm{CO}_{2}$, the precipitate of $\mathrm{BaCO}_{3}$ was transferred to an evolution flask and the evolved $\mathrm{CO}_{2}$ drawn through the absorption tower and determined by titration. The results never varied from the calculated by more than a drop of $0.4 N$ acid, which represents less than $0.5 \mathrm{mg}$. of $\mathrm{CO}_{2}$. The $\mathrm{Ba}(\mathrm{OH})_{2}$ in the tower will absorb efficiently with rapid aspiration to nearly onehalf saturation, which represents about o. I $5 \mathrm{~g}$. of $\mathrm{CO}_{2}$. With slow aspiration still more may be safely absorbed. The tower is conveniently attached to almost any form of apparatus in which $\mathrm{CO}_{2}$ is evolved for measurement. For more accurate determinations of small amounts of $\mathrm{CO}_{2}$, more dilute solutions of $\mathrm{Ba}(\mathrm{OH})_{2}$ and $\mathrm{HCl}$ should be used.

\section{SUMMARY}

I-The gravimetric determination of $\mathrm{CO}_{2}$ by weighing of absorption apparatus gives accurate results in the case of small amounts of $\mathrm{CO}_{2}$, slow aspiration, and due precautions in weighing and drying. In the case of rapid aspirations carrying considerable amounts of $\mathrm{CO}_{2}$ the gravimetric method is troublesome.

II-The determination of $\mathrm{CO}_{2}$ by absorption in alkali hydroxide and double titration has many disadvantages. The amount of indicator used needs to be carefully regulated and standard end points should be used. Under the best conditions, the end points are not sharp, making it absolutely unusable by some people. Good results can be obtained in the case of people having a good eye for color by observing the necessary precautions, but this leads to a great deal of inconvenience.

III-A new form of tower, described above, makes possible the use of $\mathrm{Ba}(\mathrm{OH})_{2}$ as an absorbing medium for $\mathrm{CO}_{2}$ under nearly all conditions. It also eliminates practically all contamination of $\mathrm{CO}_{2}$ from the air, and greatly facilitates the washing. The titration has the advantage of a very good end point. The standard solution of $\mathrm{Ba}(\mathrm{OH})_{2}$ is easily prepared free of carbonates.

DEPARTMENT OF SOIL, WiscoNSIY EXPERIMENT STATION University of Wisconsin, Madison

THE AMINO ACID NITROGEN OF SOIL

By R. S. POTTER AND R. S. SNYDER

Received June 24, 1915

INTRODUCTION

The importance of the amino acids as the chief products of the chemical, and under some conditions, of the biological decomposition of protein material, makes desirable a quantitative knowledge regarding their occurrence in the soil. While there is, no doubt, present in the soil representatives of all the classes of compounds between undecomposed protein and ammonia and nitrates, yet there are no methods which have been applied to the quantitative determination of any of these classes of compounds except ammonia, nitrates, and nitrites, which together make up but a small proportion of the total nitrogen compounds. It would seem, therefore, that a more complete knowledge of the nitrogen of the soil is very important from an academic and a practical standpoint. In this investigation, our attention has been confined to the amino acid nitrogen. Many investigators have found amino acids in soil after subjecting it to hydrolysis, but there has been no quantitative determination of the amino acids as such. In fact, the only investigations showing the presence of amino acids in the soil were made by Shreiner and Shorey, who found histidine, arginine, ${ }^{1}$ and lysine, ${ }^{2}$ in a weak alkali extract of soil. ${ }^{3}$

Except for the work of Chardet, which has not been confirmed, the only proof there is of the presence of amino acids in the soil is the work of Schreiner and Shorey. Until quite recently, there has been no method sufficiently sensitive to permit of the accurate determination of the amino acids in the soil, but the copper method of Kober, ${ }^{4}$ being capable of detecting, with considerable accuracy, one part of amino acid nitrogen in 500,000 parts of solution, has been found very suitable for soil work. By this method 5 to 30 parts of amino acid nitrogen per million parts of soil have been found, so it can easily be seen how the earlier methods would be entirely unsuited. The formol titration method of Soerensen ${ }^{5}$ has been shown

I J. Biol. Chem., $8(1910), 382$.

2 U. S. Dept. Agric., Bur. of Soils, Bull. 88 (1913).

3 Since the experimental part of this paper was completed, Chardet (Rev. gên. chem., 17, 137) reports the analysis of 4 soils for amino acid nitrogen by the Soerensen method. He found from 49 to 68 per cent of the total nitrogen was amino acid nitrogen. Following his directions, as given, we have been unable to find an appreciable amount of amino acid nitrogen in any of several soils examined.

4 J. Am. Chem. Soc., 35 (1913), 1546.

5 Z. physiol. Chem., 64 (1910), 120. 